\title{
Pro-apoptotic and anti-proliferative effects of corn silk extract on human colon cancer cell lines
}

\author{
HAO GUO, HONG GUAN, WENQIN YANG, HAN LIU, HUILING HOU, XUE CHEN, \\ ZHENYAN LIU, CHUANGANG ZANG, YUCHAO LIU and JICHENG LIU

\begin{abstract}
Research Center of Microecological Engineering Technology, Qiqihar Medical University, Qiqihar, Heilongjiang 161006, P.R. China
\end{abstract}

Received July 5, 2015; Accepted November 11, 2016

DOI: $10.3892 / \mathrm{ol} .2016 .5460$

\begin{abstract}
Corn silk is an economically and nutritionally significant natural product as it represents a staple food for a large proportion of the world population. This study investigated the anticancer activity of corn silk extract in human colon cancer cells and human gastric cancer cells. Following treatment with corn silk extract, certain apoptosis-related events were observed, including inhibition of cell proliferation, loss of mitochondrial membrane potential $(\Delta \Psi \mathrm{m})$, release of $\mathrm{Ca}^{2+}$ and release of cytochrome $c$ from the mitochondria into the cytosol. Our results revealed that corn silk extract inhibited the proliferation of cancer cells and increased the level of apoptosis in a concentration-dependent manner. Western blot analysis revealed that corn silk extract upregulated the levels of Bax, cytochrome $c$, caspase-3 and caspase-9, but downregulated the levels of B-cell lymphoma 2. These results suggest that corn silk extract may induce apoptosis through the mitochondria-mediated pathway.
\end{abstract}

\section{Introduction}

Colon cancer is one of the most prevalent cancers throughout the world, and particularly in Western countries (1). There has been an increase in the number of studies aiming to identify novel sources of bioactive compounds that prevent colon cancer. Bioactive compounds of natural origin, particularly from a dietary source, are of significant interest (2).

Plants have a long history of use in the treatment of a number of forms of cancer, and they provide leads for the development of potential novel agents. Corn silk is made from the stigmas and styles of the maize plant belonging to the grass family (3) and it is a well-known traditional functional food

Correspondence to: Professor Jicheng Liu or Professor Hong Guan, Research Center of Microecological Engineering Technology, Qiqihar Medical University, 333 Bukui North Street, Qiqihar, Heilongjiang 161006, P.R. China

E-mail: liujichengqiqi@yahoo.com

E-mail: 676639614@qq.com

Key words: corn silk, human colon cancer cells, apoptosis, mitochondria-mediated and Chinese herbal medicine, which has significant effects on human health (4). It has been reported that consumption of corn silk has no adverse effects and that it is safe for human use. Previous studies have confirmed the presence of multiple bioactive compounds in corn silk, including proteins, polysaccharides (5), flavonoids (6), vitamins, tannins, alkaloids, mineral salts (7) and steroids. There have been numerous studies on the bioactivity of corn silk constituents, including its antitumor capacities (8), anti-diabetic activity in hyperglycemia rats (5) and anti-fatigue activity (9). In our preliminary experiments, corn silk extract was noted to inhibit cell growth and trigger apoptosis (8). However, the specific active ingredients in corn silk extract that induce cancer cell apoptosis remain unknown.

In the present study we investigated whether corn silk extract could induce apoptosis through the mitochondrial pathway in LoVo human colon cancer cells, and whether it could affect cell proliferation, cell cycle progression and protein expression.

\section{Materials and methods}

Chemicals and reagents. Collected corn silk was extracted in hot water three times and filtered; the brown filtrate with most of the small soluble compounds was removed. The rest of the corn silk was air-dried and then pulverized into a homogeneous size by a disintegrator. To obtain aqueous extracts, corn silk (500 g per sample) was resuspended in $500 \mathrm{ml} 96^{\circ} \mathrm{C}$ hot water for $1 \mathrm{~h}$ at $100^{\circ} \mathrm{C}$. Then, the extract was obtained by centrifugation, filtering through a filter paper and cellulose ester membrane with $0.22-\mu \mathrm{m}$ pores, followed by freeze-drying. Corn silk extract, a light brown powder, was dissolved in Dulbecco's modified Eagle's medium (DMEM), filtered through a $0.22-\mu \mathrm{m}$ filter and stored at $-20^{\circ} \mathrm{C}$.

DMEM and RPMI-1640 medium were purchased from Gibco Chemical Co. (Invitrogen Life Technologies, Carlsbad, CA, USA). Fetal bovine serum (FBS), ampicillin sodium and streptomycin sulfate were purchased from Sangon Biological Engineering Technology and Services Co., Ltd. (Shanghai, China). 3-(4,5-dimethylthiazol-2-yl)-2, 5-diphenyl tetrazolium bromide (MTT) was purchased from Amersco (Cleveland, OH, USA). A DNA purification kit was purchased from Promega Corporation (Madison, WI, USA). 
3,3'-dihexyloxacarbocyanine (DiOC6) and Fluo-3/AM were purchased from Beyotime Biological Company (Shanghai, China). Antibodies against caspase-3, caspase-9, cytochrome $c$, B-cell lymphoma 2 (Bcl-2), Bax and goat anti-rabbit IgG were obtained from ComWin Biotechnology Company (Beijing, China).

Corn silk extract composition analysis. The extraction of proteins was determined according to the Kjeldahl method (10); total sugar was determined by the phenol-sulfuric acid assay (11) and reducing sugar by the 3,5-dinitrosalicylic acid (DNS) assay (12).

Cell culture. LoVo and HT-29 human colon cancer cells and MGC-803 human gastric cancer cells were purchased from the Type Culture Collection of the Chinese Academy of Sciences (Shanghai, China). LoVo and MGC-803 cells were cultured in DMEM, and HT-29 cells were cultured in RPMI-1640, containing $10 \%$ FBS, ampicillin sodium and streptomycin sulfate. All cells were cultivated under standard conditions at $37^{\circ} \mathrm{C}$ in a humidified atmosphere containing $5 \% \mathrm{CO}_{2}$.

Cell proliferation assay. The effects of corn silk extract on cell proliferation were evaluated by MTT assay. The cells were harvested during the logarithmic growth phase and seeded at a density of $2 \times 10^{4}$ cells/well in $96-$-well plates. Following overnight growth, the culture medium was replaced with various concentrations $(1.25,2.5,5.0,10.0$ and $20.0 \mathrm{mg} / \mathrm{ml})$ of corn silk extract for 24, 48 and $72 \mathrm{~h}$. Approximately $100 \mu \mathrm{l}$ MTT was added to each well for $4 \mathrm{~h}$. Subsequently, the supernatant was removed and the MTT crystals were dissolved in $200 \mu \mathrm{l}$ dimethyl sulfoxide. Thereafter, the absorbance was measured at $570 \mathrm{~nm}$ using an enzyme-linked immunosorbent assay plate reader.

The $50 \%$ inhibitory concentration $\left(\mathrm{IC}_{50}\right)$ was determined as the anticancer drug concentration causing a $50 \%$ reduction in cell viability, and calculated from the cytotoxicity curves. Cell survival (percent) was calculated using the following formula: survival $(\%)=[($ mean experimental absorbance $) /($ mean control absorbance)] x $100 \%$.

Cell cycle analysis. LoVo cells were seeded in a six-well plate at a density of $5 \times 10^{5}$ cells/well and treated with various concentrations $(5.0,10.0$ and $20.0 \mathrm{mg} / \mathrm{ml})$ of corn silk extract for $48 \mathrm{~h}$. Then, the cells were trypsinized, collected, washed with cold phosphate-buffered saline (PBS) and fixed in 70\% ethanol at $-20^{\circ} \mathrm{C}$ overnight. The cells were incubated with RNase A $(0.1 \mathrm{mg} / \mathrm{ml})$ and propidium iodide (PI; $50 \mathrm{mg} / \mathrm{l})$ in the dark for $30 \mathrm{~min}$. The cell cycle distribution and the percentage of apoptotic cells (sub-G1 fraction) were determined by flow cytometry (13).

DNA gel electrophoresis. LoVo cells were seeded in a six-well plate at a density of $5 \times 10^{5}$ cells/well, incubated with various concentrations $(1.25,2.5,5.0,10.0$ and $20.0 \mathrm{mg} / \mathrm{ml})$ of corn silk extract for 24, 48 and $72 \mathrm{~h}$, and then harvested. The cells were lysed in a cell lysis buffer $(10 \mu \mathrm{mol} / \mathrm{ml}$ Tris- $\mathrm{HCl}, 10 \mu \mathrm{mol} / \mathrm{ml}$ EDTA, $0.5 \%$ Triton $\mathrm{X}-100)$ at $4^{\circ} \mathrm{C}$ for $4 \mathrm{~min}$. Following centrifugation, the supernatant was treated with RNase A $(20 \mathrm{mg} / \mathrm{ml})$ and proteinase $\mathrm{K}(20 \mathrm{mg} / \mathrm{ml})$ for $30 \mathrm{~min}$ at $37^{\circ} \mathrm{C}$. Then, DNA was extracted by $\mathrm{NaCl}$-isopropanol $(1: 6)$ at $-20^{\circ} \mathrm{C}$ overnight. The extracted DNA was resuspended and loaded in each well, and DNA gel electrophoresis was performed using $1.5 \%$ agarose gel. Following ethidium bromide staining, images of the DNA ladders were captured under UV as previously described (14).

Determination of mitochondrial transmembrane potential $(\Delta \Psi \mathrm{m})$ and $\mathrm{Ca}^{2+}$ levels. LoVo cells were seeded in six-well plates at a density of $2 \times 10^{5}$ cells/well. Following treatment with various concentrations $(5.0,10.0$ and $20.0 \mathrm{mg} / \mathrm{ml})$ of corn silk extract for $48 \mathrm{~h}$, the cells were pelleted by centrifugation for $5 \mathrm{~min}$, washed in cold PBS twice and loaded with specific fluorochromes. For $\Delta \Psi \mathrm{m}$ analysis, the cells were resuspended in $0.5 \mu \mathrm{l} \mathrm{DiOC6}(40 \mu \mathrm{mol} / \mathrm{l})$, incubated at $37^{\circ} \mathrm{C}$ for $30 \mathrm{~min}$ in the dark and analyzed by flow cytometry as previously described $(15,16)$.

To detect $\mathrm{Ca}^{2+}$ release, the cells were resuspended in $1 \mu \mathrm{l}$ Fluo-3/AM $(5 \mu \mathrm{mol} / \mathrm{l})$ and incubated at $37^{\circ} \mathrm{C}$ for $30 \mathrm{~min}$ in the dark. Following incubation, the cells were washed twice with PBS and analyzed by flow cytometry as previously described $(16,17)$.

Western blot analysis. LoVo cells were seeded in six-well plates at a density of $2 \times 10^{5}$ cells/well and incubated with various concentrations $(5.0,10.0$ and $20.0 \mathrm{mg} / \mathrm{ml})$ of corn silk extract for $48 \mathrm{~h}$. The cells were harvested and extracted using a nuclear and cytoplasmic extraction kit. Then, the proteins were resolved by sodium dodecyl sulphate-polyacrylamide gel electrophoresis. The separated proteins were transferred to polyvinylidene difluoride membranes and blocked with bovine serum albumin blocking buffer for $2 \mathrm{~h}$ at room temperature. The membranes were incubated with specific antibodies overnight at $4^{\circ} \mathrm{C}$ and washed three times with Tris-buffered saline containing $0.1 \%$ Tween-20. On the second day, the membranes were incubated with the relevant secondary antibodies $(1: 2,000)$ for $90 \mathrm{~min}$ at room temperature. Finally, the transferred proteins were visualized using diaminobenzidine as previously described $(18,19)$.

Statistical analysis. All data are presented as the means \pm standard deviation of three experiments. Statistical differences between corn silk extract-treated and control groups were evaluated using Student's t-test with SPSS 18.0 (SPSS, Inc., Chicago, IL, USA). P $<0.05$ was considered to indicate a statistically significant difference.

\section{Results and Discussion}

Corn silk extract composition analysis. As shown in Table I, corn silk extract contained $21.80 \%$ proteins, $51.70 \%$ total sugar and $10.43 \%$ reducing sugar (Table I). In a previous study, Ooi and Liu observed that the anticancer activity of polysaccharides may be a consequence of the stimulation of cell-mediated immune response (20). In another study, Yang et al demonstrated that corn silk polysaccharides not only inhibited the tumor growth, but also extended the survival time of H22 tumor-bearing mice (21). Food proteins may be considered as a source of nutraceutical peptides and amino acids that exert biological functions to promote health and prevent disease, including cancer (22). 
Table I. Results of corn silk extract composition analysis.

\begin{tabular}{lc}
\hline Composition & Content/\% \\
\hline Total sugar & 51.70 \\
Reducing sugar & 10.43 \\
Proteins & 21.80 \\
Moisture content & 11.40
\end{tabular}

A

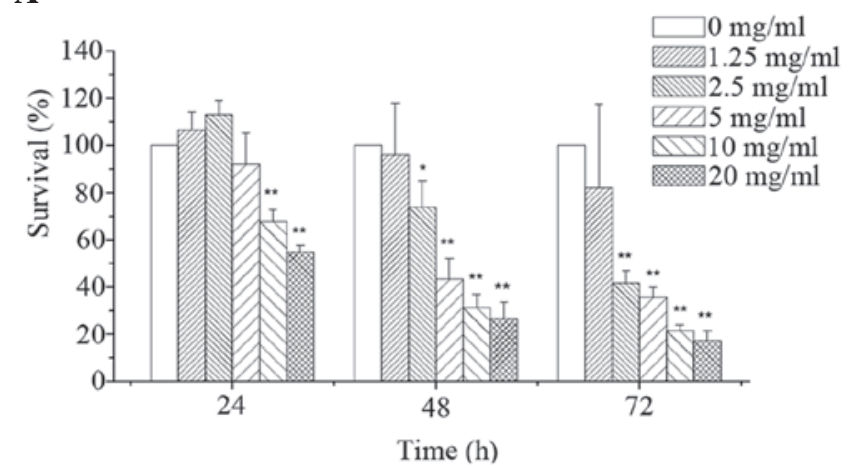

B

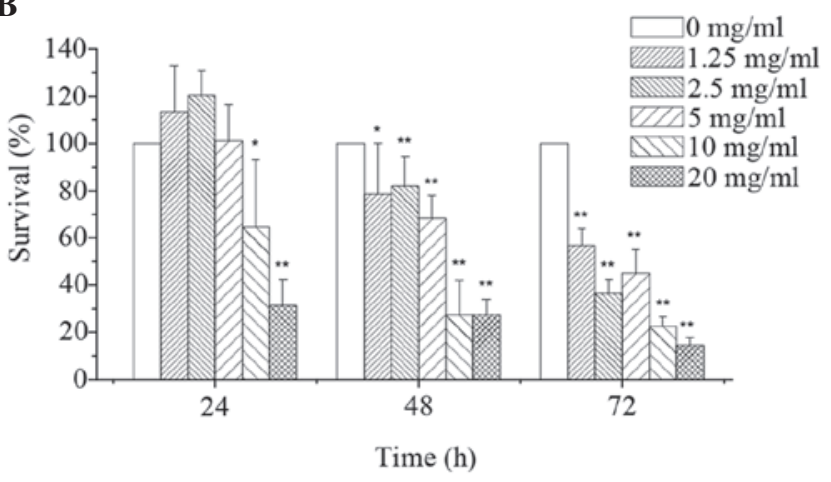

C

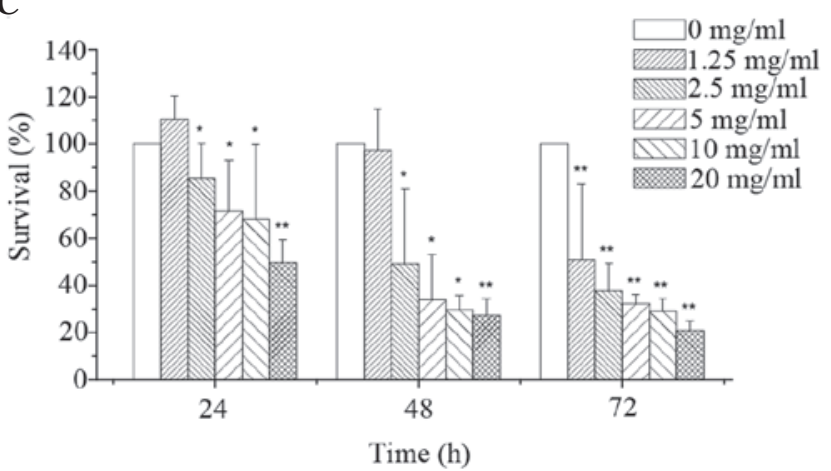

Figure 1. Effects of corn silk extract on proliferation of MGC-803 cells (A), HT-29 cells (B) and LoVo cells (C). The cells were exposed to various concentrations of corn silk extract for 24,48 and $72 \mathrm{~h}$. Data are presented as the means \pm standard deviation of three independent experiments. ${ }^{*} \mathrm{P}<0.05$, ${ }^{* *} \mathrm{P}<0.01$, compared with the control sample.

Effects of corn silk extract on cell proliferation of cancer cells. As shown in Fig. 1, MTT assay revealed that corn silk extract inhibited cell proliferation in a dose- and time-dependent manner. By integrating these data, the $48 \mathrm{~h} \mathrm{IC}_{50}$ of corn silk extract on MGC-803 cells (Fig. 1A), HT-29 cells (Fig. 1B) and LoVo cells (Fig. 1C) was 6.09, 5.38 and $4.52 \mathrm{mg} / \mathrm{ml}$,
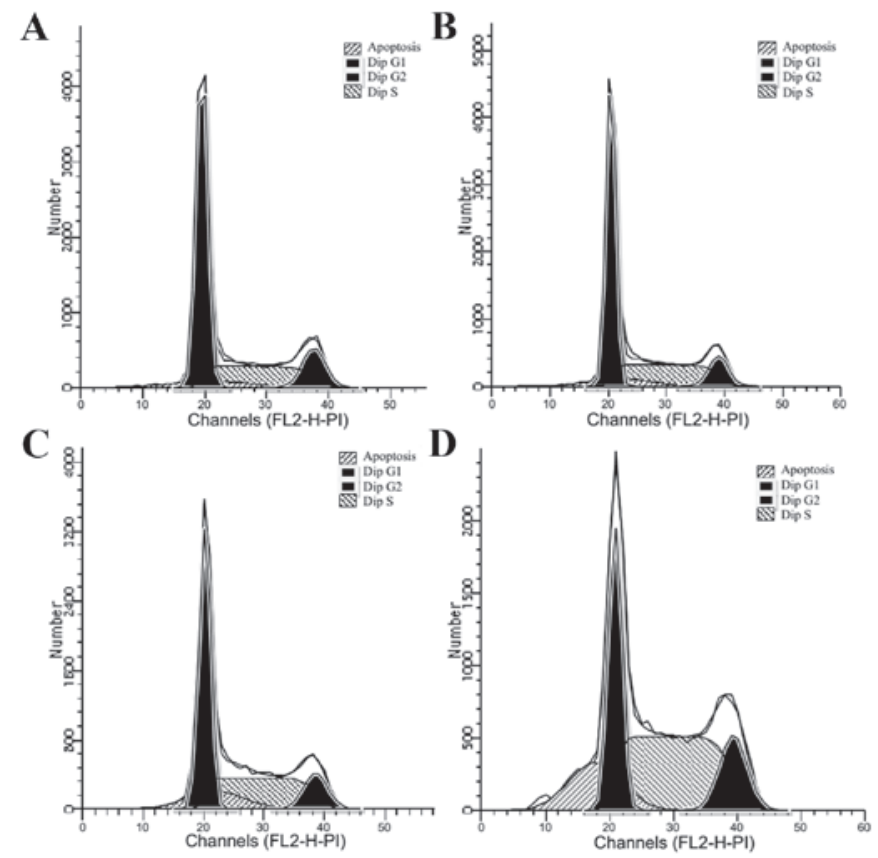

E

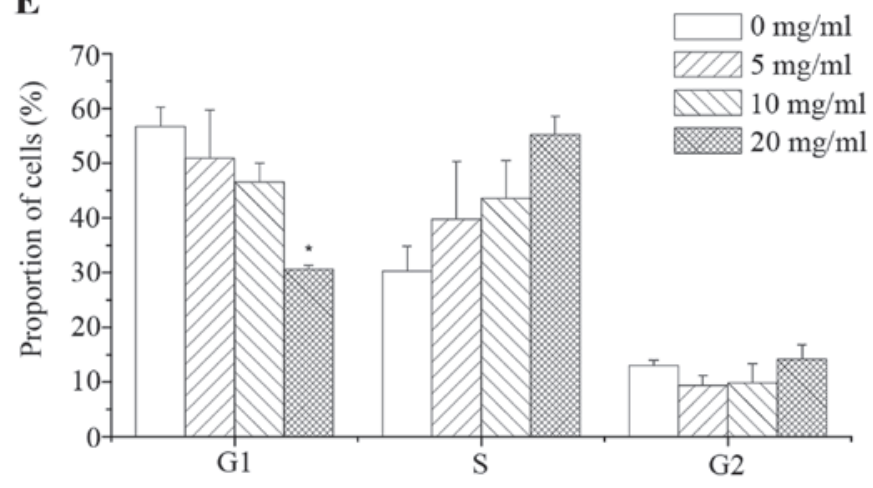

Figure 2. Effects of corn silk extract on cell cycle distribution. LoVo cells were treated with (A) 0 , (B) 5 , (C) 10 and (D) $20 \mathrm{mg} / \mathrm{ml}$ corn silk extract for $48 \mathrm{~h}$ then stained with propidium iodide for flow cytometry analysis. The histograms reveal the percentage of cells in the indicated phases of the cycle. (E) The graph reveals the distribution of cells in different phases of the cell cycle by flow cytometry in LoVo cells, and demonstrates that corn silk extract arrests cells in the $\mathrm{S}$ phase. Data are presented as the means \pm standard deviation of at least three independent experiments. ${ }^{*} \mathrm{P}<0.05$ compared with the control sample.

respectively. Compared with the MGC-803 cells and HT-29 cells, LoVo cells were more sensitive to corn silk extract and thus were used to explore the related mechanism of corn silk extract-induced apoptosis in LoVo cells.

Effects of corn silk extract on cell cycle arrest in LoVo cells. PI staining was used to detect the effects of corn silk extract at various concentrations on colon cancer cells. Forty-eight hours after treatment, a sub-diploid peak was present in the left part of the graph. With the increase in corn silk extract concentration, the sub-diploid peak became increasingly evident, representing a gradient of mortality. As shown in Fig. 2A to D, the sub-G1 fractions in the corn silk extract-treated groups were 7.86, 12.93 and $16.44 \%$, which was significantly higher than the $4.71 \%$ of the negative control group. These results reveal that corn silk extract has a significant inhibitory effect on cancer cell growth. Moreover, the sub-G1 fraction was increased in 


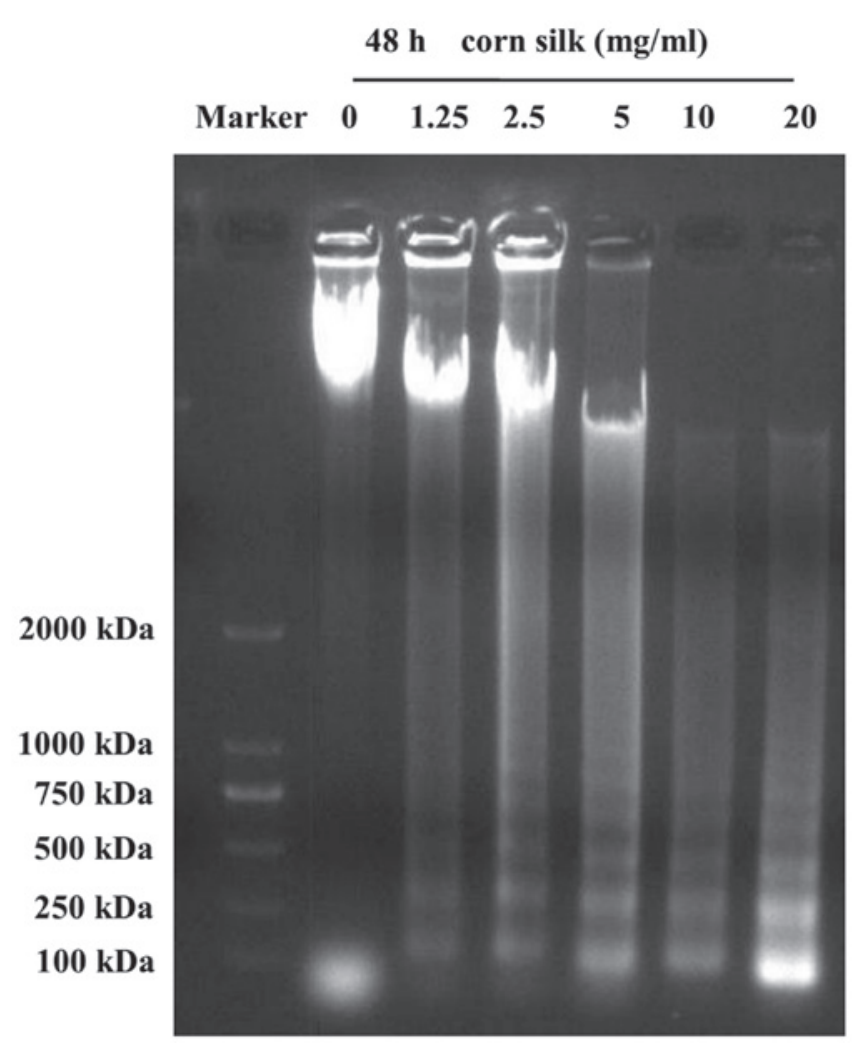

Figure 3. Effects of corn silk extract on DNA fragmentation and apoptosis in LoVo cells. The results revealed that DNA was isolated for DNA gel electrophoresis.

a drug concentration-dependent manner. As shown in Fig. 2E, flow cytometry revealed that the percentage of cells in the G1 phase was $56.56,50.92,46.57$ and $30.62 \%$ following treatment with $0,5,10$ and $20 \mathrm{mg} / \mathrm{ml}$ corn silk extract, respectively, for $48 \mathrm{~h}$. The number of S-phase cells was $30.28,39.72,43.57$ and $55.21 \%$ with $0,5,10$ and $20 \mathrm{mg} / \mathrm{ml}$ corn silk extract for $48 \mathrm{~h}$. The data revealed that the relative proportion of cells in the S phase increased when the concentration of corn silk extract was increased. Experiments revealed that the corn silk extract inhibited the proliferation of cells mainly through S-phase arrest, blocking cells from entering the G2/M phase of mitosis. Correspondingly, cells in the sub-G1 phase were also increased in a drug concentration-dependent manner, which was consistent with the flow cytometry data. Therefore, the cell cycle inhibitory effect of the corn silk extract mainly involved S-phase arrest.

Effects of corn silk extract on DNA fragmentation and apoptosis in LoVo cells. As shown in Fig. 3, the formation of the DNA ladder occurred $48 \mathrm{~h}$ after treatment with corn silk extract, and this effect was concentration-dependent from $1.25 \mathrm{mg} / \mathrm{ml}$ up to a maximum of $20 \mathrm{mg} / \mathrm{ml}$. We observed that, in contrast to the control group, treatment of LoVo cells with corn silk extract for $48 \mathrm{~h}$ resulted in internucleosomal DNA fragmentation consisting of 180-200 bp, a characteristic of apoptosis, exhibiting a typical ladder-like pattern of degraded DNA products on agarose gel electrophoresis. A previous study reported that in the event of apoptosis, DNA gel electrophoresis exhibited a clear ladder. DNA gel electrophoresis is considered one of the gold standards in the determination of apoptosis (23).

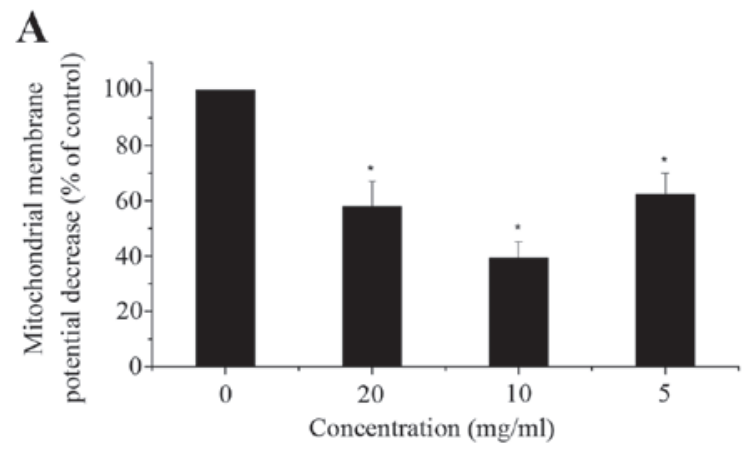

B

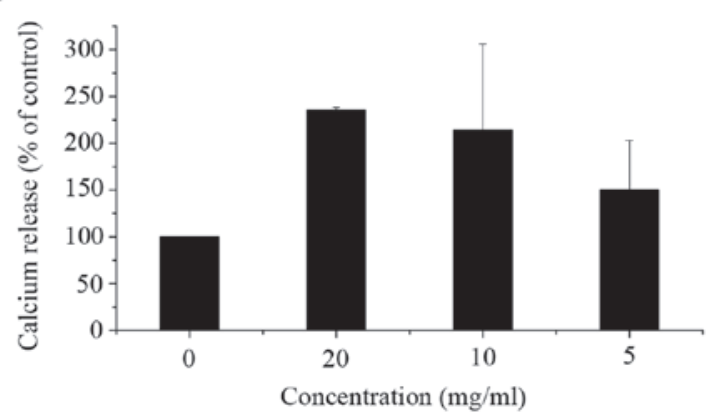

Figure 4. Effects of corn silk extract on mitochondrial membrane potential $(\Delta \Psi \mathrm{m})$ and releasing $\mathrm{Ca}^{2+}$ in LoVo cells. Cells were treated with various concentrations of corn silk extract for $48 \mathrm{~h}$, and then harvested for staining by 3,3'-dihexyloxacarbocyanine and Fluo-3/AM for $\Delta \Psi \mathrm{m}(\mathrm{A})$ and $\mathrm{Ca}^{2+}(\mathrm{B})$. ${ }^{*} \mathrm{P}<0.05$ compared with the control sample.

Effects of corn silk extract on mitochondrial membrane potential and $\mathrm{Ca}^{2+}$ release from LoVo cells. Flow cytometric analysis indicated a significant decrease in mitochondrial membrane potential $(\Delta \Psi \mathrm{m})($ Fig. $4 \mathrm{~A})$ and a significant increase in cytosolic $\mathrm{Ca}^{2+}$ levels (Fig. 4B) in corn silk extract-treated cells when compared with the control cells. As illustrated in Fig. 4A, in LoVo cells exposed to corn silk extract for $48 \mathrm{~h}$, $\Delta \Psi \mathrm{m}$ was decreased, particularly in the $10 \mathrm{mg} / \mathrm{ml}$ dose group. Cytosolic $\mathrm{Ca}^{2+}$ release increased. As shown in Fig. 4B, cytosolic $\mathrm{Ca}^{2+}$ levels peaked in the $10-\mathrm{mg} / \mathrm{ml}$ dose group, with levels being higher than those of the control cells at $48 \mathrm{~h}$. In the mitochondrial apoptosis pathway, the decrease in mitochondrial membrane potential is an early event in apoptosis. It was reported that the proteins extracted from corn silk could decrease mitochondrial membrane potential (22), which is in accordance with our results. However, in the low-dose group, the mitochondrial membrane potential was increased compared with other corn silk extract-treated groups, which may be related to the selection of cells. The elevation of calcium ion levels is associated with signal transduction in the early stages of apoptosis. Mitochondria represent one of the intracellular calcium pools. It was reported that stored $\mathrm{Ca}^{2+}$ was released from the mitochondria, which significantly increased the intracellular calcium level in the early stages of apoptosis (24). This process was synergized by other pro-apoptotic factors leading to apoptosis of a large number of cells. This indicates that corn silk extract could induce apoptosis through the upregulation of intracellular $\mathrm{Ca}^{2+}$ levels. Fan et al reported that the changes of intracellular calcium homeostasis and $\Delta \Psi \mathrm{m}$ could contribute to apoptosis in treated cells (23). 
Corn silk $(\mathrm{mg} / \mathrm{ml})$

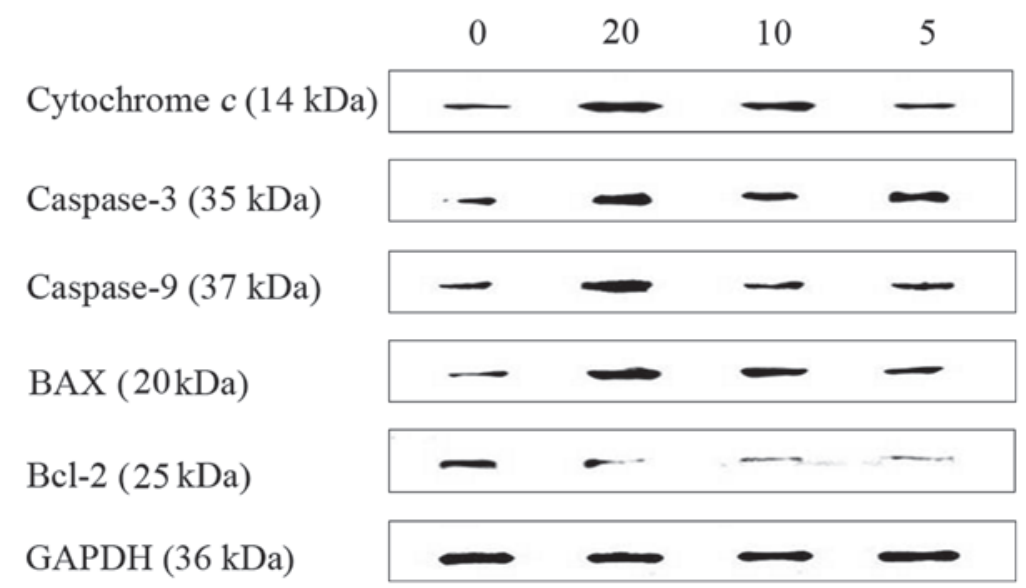

Figure 5. Effects of corn silk extract on apoptosis-associated proteins in LoVo cells. Cells were treated with various concentrations of corn silk extract for $48 \mathrm{~h}$, then apoptosis-associated proteins were examined by western blot analysis as described in Materials and methods. Bcl-2, B-cell lymphoma 2.

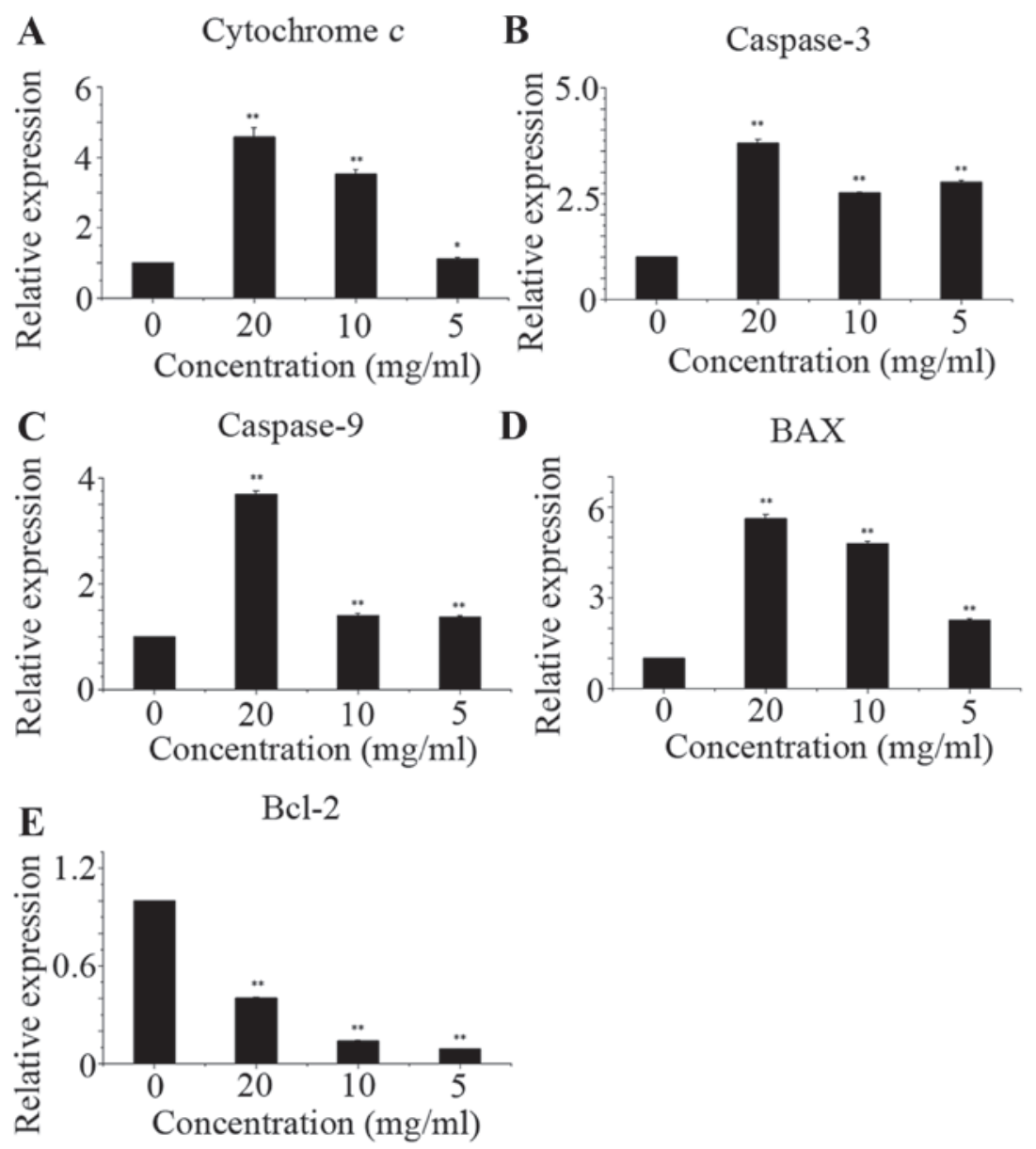

Figure 6. Effects of corn silk extract on apoptosis-associated proteins in LoVo cells. Western blot analysis data are presented as the relative expression of selected proteins compared with GAPDH. Data are presented as the means \pm standard deviation of at least three independent experiments. ${ }^{*} \mathrm{P}<0.05,{ }^{* *} \mathrm{P}<0.01$, compared with the control sample. Bcl-2, B-cell lymphoma 2.

Effects of corn silk extract on apoptosis-associated protein expression in LoVo cells. As shown in Fig. 5, corn silk extract upregulated the levels of cytochrome $c$, caspase-3, caspase- 9 and Bax, but reduced the levels of Bcl-2, which led to apoptosis. Western blot analysis data are presented as the relative expression of selected proteins compared with
GAPDH (Fig. 6). Using western blot assay, we have shown above that apoptotic pathway induction by corn silk extract treatment was mediated by affecting the Bax and Bcl-2 levels, causing dysfunction of mitochondria, promoting the release of cytochrome $c$ and activating caspase- 9 and caspase-3 $(15,25)$. 
Caspase is a family of proteases that plays a significant role in the process of apoptosis. Caspase-9 is involved in the upstream stages of the signal transduction cascade of apoptosis. Following the release of cytochrome $c$ from mitochondria, caspase-9 is activated to form a complex with cytochrome $c$. The activation of caspase- 9 then activates caspase- 3 , thereby facilitating subsequent apoptotic signaling. Caspase- 3 is a key enzyme in the apoptotic cascade, playing an essential role in chromatin condensation, DNA fragmentation and other nuclear apoptotic processes (26). This further supports the hypothesis that corn silk extract significantly induced apoptosis in LoVo cells. Bcl-2 family proteins also play crucial roles in apoptosis. This family consists of two types of proteins: anti-apoptotic and pro-apoptotic. It was demonstrated that the change in mitochondrial outer membrane permeability could lead to apoptosis, and this change could be directly mediated by the Bcl-2 family proteins. In addition, the main activity of the $\mathrm{Bcl}-2$ family proteins takes place on the mitochondrial membrane (27). In the present study, the decrease in the $\mathrm{Bcl}-2 / \mathrm{Bax}$ ratio might have led to a decrease in $\Delta \Psi \mathrm{m}$ and subsequent activation of caspase- 3 via the cytochrome $c$ and caspase-9 pathway. Corn silk extract induced LoVo cell apoptosis features, including nuclear condensation, DNA fragmentation, dysfunction of mitochondria, $\mathrm{Ca}^{2+}$ production and caspase activation.

Based on the results of the present study, it is hypothesized that corn silk extract may inhibit the proliferation of LoVo cells through $\mathrm{S}$-phase arrest, and induce apoptosis through the mitochondria-mediated pathway. At present, the purification of the antitumor components of corn silk extract is in process, which is likely to aid in identifying the mechanisms underlying the antitumor activity of corn silk extract.

\section{Acknowledgements}

This study was supported by the Prophase Research Project of Transformation of Scientific and Technological Achievements of Heilongjiang Educational Committee of China under grant no. 1252CGZH04 and the Scientific Research Fund Project of Qiqihar Medical University under grant no. QY2015Q-04.

\section{References}

1. Jiang QG, Li TY, Liu DN and Zhang HT: PI3K/Akt pathway involving into apoptosis and invasion in human colon cancer cells LoVo. Mol Biol Rep 41: 3359-3367, 2014.

2. Patil JR, Chidambara Murthy KN, Jayaprakasha GK, Chetti MB and Patil BS: Bioactive compounds from Mexican lime (Citrus aurantifolia) juice induce apoptosis in human pancreatic cells J Agric Food Chem 57: 10933-10942, 2009.

3. Hu QL and Deng ZH: Protective effects of flavonoids from corn silk on oxidative stress induced by exhaustive exercise in mice. Afr J Biotechnol 10: 3163-3167, 2011.

4. Chen S, Chen H, Tian J, Wang Y, Xing L and Wang J: Chemical modification, antioxidant and $\alpha$-amylase inhibitory activities of corn silk polysaccharides. Carbohydrate polym 98: 428-437, 2013.

5. Zhao W, Yin Y, Yu Z, Liu J and Chen F: Comparison of anti-diabetic effects of polysaccharides from corn silk on normal and hyperglycemia rats. Int J Biol Macromol 50: 1133-1137, 2012.

6. Liu J and Mori A: Antioxidant and free radical scavenging activities of Gastrodia elata Bl. and Uncaria rhynchophylla (Miq.) Jacks. Neuropharmacology 31: 1287-1298, 1992.

7. Namba T, Xu H, Kadota S and Hattori M: Inhibition of IgE formation in mice by glycoproteins from corn silk. Phytother Res 7: 227-230, 1993.
8. Habtemariam S: Extract of corn silk (stigma of Zea mays) inhibits the tumour necrosis factor-alpha- and bacterial lipopolysaccharide-induced cell adhesion and ICAM-1 expression. Planta Med 64: 314-318, 1998.

9. Hu QL, Zhang LJ, Li YN, Ding YJ and Li FL: Purification and anti-fatigue activity of flavonoids from corn silk. Int J Phys Sci 5: 321-326, 2010.

10. Lynch JM and Barbano DM: Kjeldahl nitrogen analysis as a reference method for protein determination in dairy products. J AOAC Int 82: 1389-1398, 1999.

11. Rover MR, Johnston PA, Lamsal BP and Brown RC: Total water-soluble sugars quantification in bio-oil using the phenol-sulfuric acid assay. J Anal Appl Pyrolysis 104: 194-201, 2013.

12. de Wit JN: Marschall Rhône-Poulenc Award Lecture. Nutritional and functional characteristics of whey proteins in food products. J Dairy Sci 81: 597-608, 1998.

13. Tai KW, Chou MY, Hu CC, Yang JJ and Chang YC: Induction of apoptosis in KB cells by pingyangmycin. Oral Oncol 36: 242-247, 2000.

14. Lu HF, Lai TY, Hsia TC, Tang YJ, Yang JS, Chiang JH, Lu CC, Liu CM, Wang HL and Chung JG: Danthron induces DNA damage and inhibits DNA repair gene expressions in GBM 8401 human brain glioblastoma multiforms cells. Neurochem Res 35: 1105-1110, 2010.

15. Lin SY, Lai WW, Ho CC, Yu FS, Chen GW, Yang JS, Liu KC, Lin ML, Wu PP, Fan MJ and Chung JG: Emodin induces apoptosis of human tongue squamous cancer SCC-4 cells through reactive oxygen species and mitochondria-dependent pathways. Anticancer Res 29: 327-335, 2009.

16. Lu HF, Chen YS, Yang JS, Chen JC, Lu KW, Chiu TH, Liu KC, Yeh CC, Chen GW, Lin HJ and Chung JG: Gypenosides induced G0/G1 arrest via inhibition of cyclin $\mathrm{E}$ and induction of apoptosis via activation of caspases-3 and -9 in human lung cancer A-549 cells. In Vivo 22: 215-221, 2008.

17. Wu CC, Lin JP, Yang JS, Chou ST, Chen SC, Lin YT, Lin HL and Chung JG: Capsaicin induced cell cycle arrest and apoptosis in human esophagus epidermoid carcinoma CE 81T/VGH cells through the elevation of intracellular reactive oxygen species and $\mathrm{Ca}^{2+}$ productions and caspase-3 activation. Mutat Res 601: 71-82, 2006.

18. Mohan KV, Gunasekaran P, Varalakshmi E, Hara Y and Nagini S: In vitro evaluation of the anticancer effect of lactoferrin and tea polyphenol combination on oral carcinoma cells. Cell Biol Int 31: 599-608, 2007.

19. Zheng L, Wang X, Luo W, Zhan Y and Zhang Y: Brucine, an effective natural compound derived from nux-vomica, induces G1 phase arrest and apoptosis in LoVo cells. Food Chem Toxicol 58: 332-339, 2013.

20. Ooi VE and Liu F: Immunomodulation and anti-cancer activity of polysaccharide-protein complexes. Curr Med Chem 7: 715-729, 2000.

21. Yang J, Li X, Xue Y, Wang N and Liu W: Anti-hepatoma activity and mechanism of corn silk polysaccharides in $\mathrm{H} 22$ tumor-bearing mice. Int J Biol Macromol 64: 276-280, 2014.

22. Lee J, Lee S, Kim SL, Choi JW, Seo JY, Choi DJ and Park YI: Corn silk maysin induces apoptotic cell death in PC-3 prostate cancer cells via mitochondria-dependent pathway. Life Sci 119: 47-55, 2014.

23. Fan MJ, Lin YC, Shih HD, Yang JS, Liu KC, Yang ST, Lin CY, Wu RS, Yu CS, Ko YC and Chung JG: Crude extracts of Agaricus brasiliensis induce apoptosis in human oral cancer CAL 27 cells through a mitochondria-dependent pathway. In Vivo 25: 355-366, 2011 .

24. Wang L, Hu T, Shen J, Zhang L, Li LF, Chan RL, Li MX, Wu WK and Cho $\mathrm{CH}$ : Miltirone induced mitochondrial dysfunction and ROS-dependent apoptosis in colon cancer cells. Life Sci 151: 224-234, 2016.

25. Abdel-Latif AM, Abuel-Ela HA and El-Shourbagy SH: Increased caspase- 3 and altered expression of apoptosis-associated proteins, Bcl-2 and Bax in lichen planus. Clin Exp Dermatol 34: 390-395, 2009.

26. Su TR, Tsai FJ, Lin JJ, Huang HH, Chiu CC, Su JH, Yang YT, Chen JY, Wong BS and Wu YJ: Induction of apoptosis by 11-dehydrosinulariolide via mitochondrial dysregulation and ER stress pathways in human melanoma cells. Mar Drugs 10: 1883-1898, 2012.

27. Wu Z, Liu B, Cailing E, Liu J, Zhang Q, Liu J, Chen N, Chen R and Zhu R: Resveratrol inhibits the proliferation of human melanoma cells by inducing G1/S cell cycle arrest and apoptosis. Mol Med Rep 11: 400-404, 2015. 